\title{
A COMPARATIVE ANALYSIS OF LEARNERS INTERACTION IN THE ONLINE LEARNING MANAGEMENT SYSTEMS: DOES NATIONAL CULTURE MATTER?
}

\author{
Wu Bing (bennywin2000@hotmail.com, wubing@shtvu.edu.cn) \\ Shanghai Television University, P.R. China \\ Teoh Ai Ping (apteoh@wou.edu.my) \\ Wawasan Open University, Malaysia
}

\begin{abstract}
Open and distance learning (ODL) connects learners across geographical

boundaries. Through the support of the Internet and Learning Management Systems

(LMS), learners nowadays are conveniently learning and communicating via the online mode. Nevertheless, will the cultural diversity of learners affect their learning and interaction behavior in the web-based environment? This is viewed as one of the relatively unexplored scope of research areas worthy investigating via a comparative analysis of two countries from Asia but with different contexts of society. This article investigates the learners' online interaction of two open universities, namely Shanghai TV University in China and Wawasan Open University in Malaysia. Based on the findings of this comparative study, the authors are of the opinion that national cultural diversity of learners affects and influences their learning and interaction behavior in the online platform. The effect of cultural diversity of learners is in fact prominent in several aspects in their online learning and interaction behavior as observed in the synchronous chat sessions and asynchronous forum board discussions. In order to better guide the learners as well as to eliminate the negative impact of national cultural diversity on learning outcome, several suggestions and recommendations are proposed.
\end{abstract}

Keywords: learning management systems, learners interaction, national culture, open and distance learning

In the past few decades, open and distance education has been rapidly developing in Asia as well as globally. Many researchers have studied the learner's learning from the aspects of learning material, capability to utilize information technology, the role of learners, etc. Nonetheless, the analysis of the learner's learning behavior within the context of open and distance education and the impact and influence of national cultural diversity on this mode of learning is viewed as a new area of study.

National culture can be broadly defined to include the language, behaviors, values, norms, beliefs, and practices shared by a group of people in a particular country. China has more than five thousand years of culture and the people in China are strongly influenced by the 
Confucian philosophy. For the past 30 years, China has experienced rapid economic growth as well as a more open society. Those are among the factors that have enabled the people of China to adapt to new things more easily. 'Han' is the major ethnic group in the population of China and the 'Han' language, or Mandarin language, is the official language of the country. Malaysia is located in the Southeast Asia, a country with an open economy and stable socioeconomic development. Malaysians comprise of three major ethnic groups, namely Malay, Chinese and Indians. The Malay language or Bahasa Malaysia is the official language of the country.

Table 1. Course Delivery Model of SHTVU and WOU

\begin{tabular}{|c|c|c|c|}
\hline \multicolumn{2}{|c|}{ Course Delivery Model } & SHTVU & WOU \\
\hline \multicolumn{2}{|c|}{ Printed Learning Materials } & \multicolumn{2}{|c|}{ Study units and textbooks are provided to all students } \\
\hline \multirow[t]{5}{*}{$\begin{array}{l}\text { Student support } \\
\text { services }\end{array}$} & $\begin{array}{l}\text { Face-to-face tutorial } \\
\text { sessions }\end{array}$ & $\begin{array}{l}\text { Once a week during the } \\
\text { semester } \\
\text { (2-3 hours per session) }\end{array}$ & $\begin{array}{l}\text { Once a month during the } \\
\text { semester } \\
\text { ( } 2 \text { hours per session) }\end{array}$ \\
\hline & Online learning & $\begin{array}{l}\text { Learning Management } \\
\text { System: Olclass }\end{array}$ & $\begin{array}{l}\text { Learning Management } \\
\text { System: WawasanLearn }\end{array}$ \\
\hline & Telephone tutoring & Not available & $\begin{array}{l}\text { Tutors are available for } \\
\text { telephone tutoring during } \\
\text { pre-specified time slots with } \\
\text { the learners }\end{array}$ \\
\hline & $\begin{array}{l}\text { Digital library } \\
\text { resources }\end{array}$ & \multicolumn{2}{|c|}{$\begin{array}{c}\text { E-library } \\
\text { (e-books, e-journals etc.) }\end{array}$} \\
\hline & $\begin{array}{l}\text { Regional Center } \\
\text { support }\end{array}$ & \multicolumn{2}{|c|}{$\begin{array}{l}\text { Students can go to the nearest Regional Center for } \\
\text { administrative related issues and support. }\end{array}$} \\
\hline \multirow[t]{3}{*}{$\begin{array}{l}\text { Course } \\
\text { Assessment }\end{array}$} & $\begin{array}{l}\text { Course work: } \\
\text { - Number of } \\
\text { - } \quad \text { assignments: } \\
\text { contribution: }\end{array}$ & $\begin{array}{l}3-5 \\
10-40 \%\end{array}$ & $\begin{array}{l}3 \\
50 \%\end{array}$ \\
\hline & $\begin{array}{l}\text { Contribution of } \\
\text { participation in LMS } \\
\text { towards course work } \\
\text { marks }\end{array}$ & $\begin{array}{l}\text { Supported by some } \\
\text { courses. }\end{array}$ & Not applicable. \\
\hline & $\begin{array}{l}\text { Final written } \\
\text { examination }\end{array}$ & $60 \%-90 \%$ & $50 \%$ \\
\hline \multirow{2}{*}{$\begin{array}{l}\text { Communication } \\
\text { between Course } \\
\text { Coordinator } \\
\text { and Tutors }\end{array}$} & Frequency & \multicolumn{2}{|c|}{ At least 3 times in a semester } \\
\hline & Mode & $\begin{array}{l}\text { Face-to-face, telephone, } \\
\text { email }\end{array}$ & $\begin{array}{l}\text { Face-to-face, telephone, } \\
\text { email, LMS forum } \\
\text { discussions }\end{array}$ \\
\hline
\end{tabular}

Shanghai TV University (SHTVU), as an open and distance learning (ODL) institution was established in 1960 with three campuses and 53 learning centers covering 10 undergraduate programs and 15 junior college programs which offer 31 major fields of study. Wawasan Open University (WOU) was launched in 2006 as Malaysia's first private and non-profit ODL University dedicated for adult learners. WOU currently offers 11 degree programs and has just introduced a postgraduate program. The authors are of the opinion that it is meaningful to undertake a comparative study of this area of interest, as WOU operates in a multi-cultural environment while SHTVU takes roots in the traditional framework of Chinese culture. Both 
institutions have very similar mode of delivery of courses and learners support provided, as depicted in Table 1.

To provide a facilitated web-based learning environment, both SHTVU and WOU utilize the online LMS. The LMS of SHTVU has developed in-house. It has been in use for a longer period and has a larger number of users; as compared to the open source LMS - "Moodle" adopted by WOU. It can be said that asynchronous forum boards and synchronous chat have become important features of the LMS operated by both universities. Table 2 compares some basic information of the LMS of SHTVU and WOU.

Table 2. LMS Features and Functions of SHTVU and WOU

\begin{tabular}{|c|c|c|}
\hline Features/Functions & SHTVU & WOU \\
\hline Source & Developed in-house & $\begin{array}{l}\text { Moodle - an open-source course } \\
\text { management system }\end{array}$ \\
\hline Number of users (as of June 2007) & 112,000 & 597 \\
\hline Duration in-use & Since year 2000 & Since year 2007 \\
\hline Language used in LMS & Chinese & English \\
\hline $\begin{array}{l}\text { Programming language used to } \\
\text { develop the LMS }\end{array}$ & net & PHP \\
\hline Editing capability of LMS pages & Weaker editing capability & $\begin{array}{l}\text { Stronger editing capability - GUI- } \\
\text { based }\end{array}$ \\
\hline Integration with Learning Centers & $\begin{array}{l}\text { Separate LMS platform for main } \\
\text { campus and branch } \\
\text { schools/learning centers. }\end{array}$ & $\begin{array}{l}\text { LMS for all learning centers are } \\
\text { integrated into the same platform. }\end{array}$ \\
\hline $\begin{array}{l}\text { Course coordinator monitoring of } \\
\text { tutors online teaching activities }\end{array}$ & Weaker & Stronger \\
\hline $\begin{array}{l}\text { Accessibility of previous semesters' } \\
\text { forum discussions }\end{array}$ & $\begin{array}{l}\text { Able to access previous } \\
\text { semesters' forum discussions }\end{array}$ & Not applicable \\
\hline $\begin{array}{l}\text { Statistical reporting features e.g } \\
\text { Log }\end{array}$ & Weaker & Stronger \\
\hline Functions available in LMS & \multicolumn{2}{|c|}{$\begin{array}{l}\text { Static Course Materials } \\
\text { (E.g. uploaded files, text pages, web pages, links, directories) } \\
\text { Interactive and Social Course Materials } \\
\text { (E.g. online quizzes, asynchronous forum boards, synchronous chats) }\end{array}$} \\
\hline
\end{tabular}

The efficiency of a collaborative and constructive learning environment is vital to ensure effective learning, especially in ODL. Learners participate and interact with peers and tutor in discussions not just merely to seek course related information and clarification, but also to exchange and share knowledge. Thurmond (2004) defined Interaction as:

"the learner's engagement with the course content, other learners, the instructor, and the technological medium used in the course. True interaction with other learners, the instructor and the technology results in a reciprocal exchange of information. The exchange of information is intended to enhance knowledge development in the learning environment. Ultimately, the goal of interaction is to increase understanding of the course content or mastery of the defined goals." 
Various researches were conducted to examine the dimensions of interaction in distance learning. Providing a basis for analyzing the relative significance of different types of interaction, Moore (1989) defined the three types of interaction as learner-teacher, learnercontent and learner-learner. Other researchers have also examined possible combinations of interaction based on teacher, learner and content. Kearsley (1995) noted that few studies on interactivity isolate the interactive component from other aspects of distance learning activities. Picciano (2002) distinguished interaction and presence in which the former is related to the nature of communication and influence. Robson (1996) classified interaction in terms of the pattern of exchanges between the teacher and students and highlighted the need to address pedagogical issues to maximize interaction within a web-based learning environment. Oliver, Omari, and Herrington (1997) explored the student interactions in a collaborative World Wide Web learning environment using a set of four dimensions, i.e. social, procedural, expository and cognitive. Oliver and McLoughlin (1997a, 1997b) studied the social, procedural, expository, explanatory and cognitive dimensions over various categories of exchanges between the teacher and students. Rourke et al. (1999) developed a framework for interpreting the online teaching and learning environment by analyzing the components of cognitive presence, teaching presence and social presence. High quality online participation in webbased learning promotes collaborative group support which subsequently results in quality online learning. (Garrison, 1997; Gunawardena \& Zittle, 1997) Garrison and Cleveland-Innes (2005) found that design of courses had a significant impact on the nature of the interaction and whether students approached learning in a deep and meaningful manner. Othman (2005) found high frequency communicative exchanges with instructional purposes on asynchronous forum boards which have created a positive learning environment. However, the interactions observed were lack of active collaborations at the cognitive dimension level. Harasim (1997) suggested that high rates of student participation, group interaction among students, high quality of intellectual exchange and spatial metaphors used as mental models to help students adjust to an online structured course are essential factors for successful and efficient online learning.

Hofstede $(1980,1991)$, the most widely cited author in culture-related studies, identified four dimensions, i.e. power distance, individualism/collectivism, masculinity/femininity and uncertainty avoidance in his original study. He rated 53 countries on indices for each dimension, normalized to values of 0 to 100 . The GLOBE framework extended Hofstede's work by adding some dimensions which give managers additional information in identifying and managing cultural differences (GLOBE, 2007). Many researchers found that groups of people from the same nation or society are perceived to act similarly on social, business and education context. Based on Hostede's dimensions applied to teaching and learning (Hofstede, 1986), knowledge dissemination stresses on 'impersonal truth' in small power distance societies while the large power distance societies emphasizes 'personal wisdom'. In a collectivist society, individual students will only speak up in small group settings when called upon and education is a way of obtaining or facilitating upward social mobility. This implies that obtaining paper qualifications is of higher concern than acquiring competence. Learners from feminine societies behave modestly compared to those from male-dominated societies who are assertive and competitive. In the less aggressive uncertainty-avoidance societies, students 
feel more comfortable with less structured learning situations. Prior studies developed generalizations about cultural learning styles based on an analysis of national cultural characteristics (Kim \& Bonk, 2002; Munro-Smith, 2002). Besides, different cultural dimensions would influence user perceptions about the general accessibility of the online environment (Tylee, 2001). The extent to which learning is learner-centered or teacher-centered also appears subject to cultural variation. Asian learners are generally found to be teacher-centered based on the findings of previous studies such as Bauer, Chin, and Chang (2000). Asian learners who are passive in interaction sometimes feel more comfortable contributing to the forums and chats within the context of the online environment (Bauer, Chin, \& Chang, 2000, Conner, 2000).

\section{Research Framework and Objectives}

The personal development of both learners and tutors are influenced by their respective regional or national culture. Activities and behavior of learners and tutors are frequently structured and guided by cultural norms/values and the effect is often subconsciously deep rooted. In the learning process, it is observed that learners' online interaction behavior is influenced by their cultural background. This study may be undertaken by using three indicators, namely dimensions of interaction, categories of exchanges and depth of discussions to analyze the interaction of learners in a web-based environment. Through Hofstede culture diversity framework, we demonstrate that cultural elements affect and influence learners' web-based interaction. We present our research framework in Figure 1.

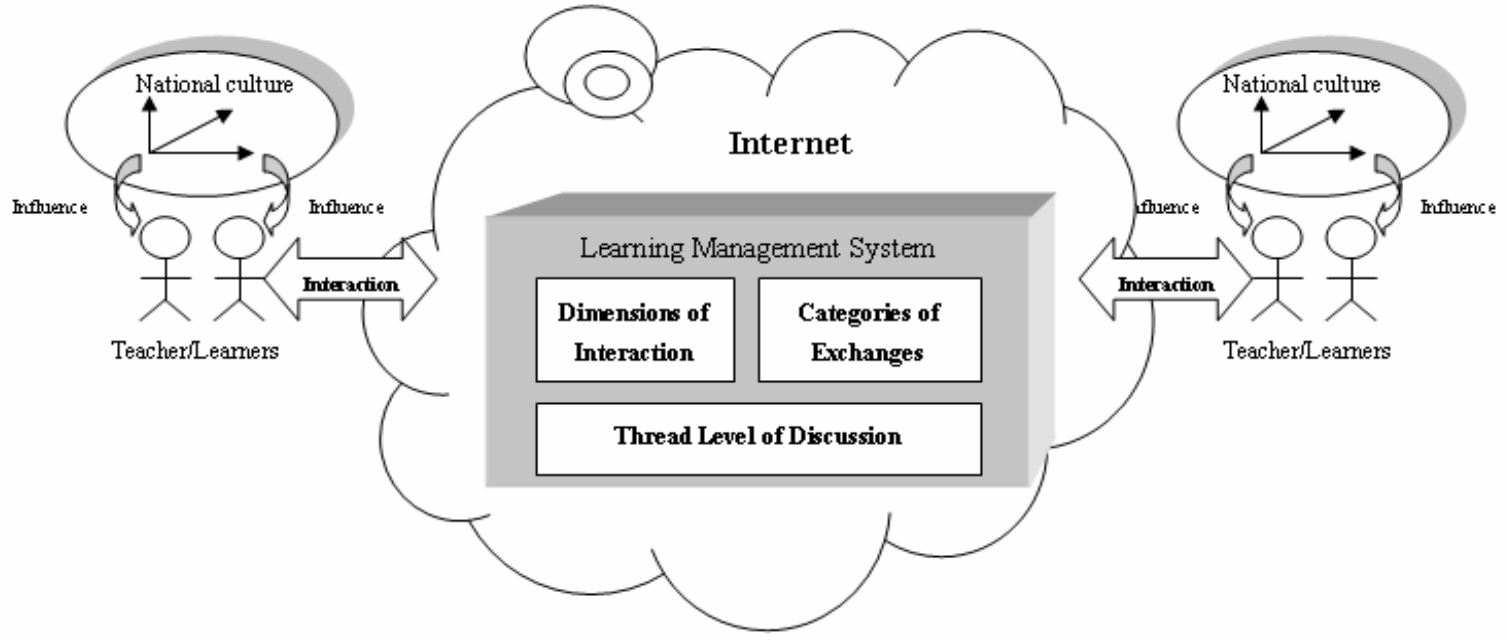

Figure 1: Research Framework

The main objective of our study is explored through the following questions:

1. Does national cultural diversity affect the learner's web-based interaction and behavior?

2. Which areas of web-based interaction are influenced by the diversity in national culture dimensions?

3. What are the strategies that would be useful to minimize the negative impact of culture on learning behavior? 


\section{METHODOLOGY}

To ensure comparability, we obtained the research data from the LMS of a similar course offered by the two institutions within the same semester, as shown in Table 3.

Table 3. Data Summary

\begin{tabular}{|l|l|l|}
\hline \multicolumn{1}{|c|}{ Items } & \multicolumn{1}{c|}{ STVU } & \multicolumn{1}{c|}{ WOU } \\
\hline Course name & Principles of Management Studies & Principles and Practice of Management \\
\hline Degree program & Bachelor of Accounting & Bachelor of Business \\
\hline $\begin{array}{l}\text { Students enrolled for } \\
\text { this course }\end{array}$ & $\begin{array}{l}\text { 1451 students } \\
\text { across 28 learning centers }\end{array}$ & $\begin{array}{l}\text { 361 students } \\
\text { across all 4 learning centers }\end{array}$ \\
\hline Sample & $\begin{array}{l}\text { The data from the main campus of } \\
\text { SHTVU and three significant learning } \\
\text { centers (were used in this study) }\end{array}$ & $\begin{array}{l}\text { Data from all four learning centers of } \\
\text { main campus were used. }\end{array}$ \\
\hline $\begin{array}{l}\text { Average age of } \\
\text { students enrolled for } \\
\text { the course }\end{array}$ & 28.4 & 32.8 \\
\hline $\begin{array}{l}\text { Language } \\
\text { background of learner }\end{array}$ & Chinese & $\begin{array}{l}\text { Comprising mainly Bahasa Malaysia, } \\
\text { Chinese, Tamil and English }\end{array}$ \\
\hline $\begin{array}{l}\text { Initiator of LMS } \\
\text { discussions }\end{array}$ & Male: $37 \%$ & $\begin{array}{l}\text { Male: } 62.7 \% \\
\text { Female: } 37.3 \%\end{array}$ \\
\hline
\end{tabular}

From our literature survey, we adopted Oliver and McLoughlin's Dimensions of Interaction which explores the dimensions of interaction by classifying interaction activity into five parts, i.e. social, procedural, expository, explanatory and cognitive. Social dimension can be defined as to include discussions of a social nature which are not directly associated with the course content. Procedural dimension involves explanation on course related procedures, requirements and administrative issues. Expository dimension involves demonstration of knowledge/facts without much further elaboration while explanatory dimension refers to elaborate explanation on knowledge and developed content based on learner's response. Finally, cognitive involves providing constructive feedback and detailed commentary on course content via critical thinking which leads to knowledge development.

We categorized the content of the web-based interaction - by initiator and respondents, into six groups, as depicted by Table 4 .

Table 4. Categories of Exchanges

\begin{tabular}{|l|l|l|}
\hline Group & \multicolumn{1}{|c|}{ Initiator and Respondents } & \multicolumn{1}{c|}{ Explanation } \\
\hline 1. & course coordinator $\rightarrow$ groups (CC-G) & $\begin{array}{l}\text { Course coordinator initiates a discussion and addresses it to } \\
\text { all groups of students at learning centers }\end{array}$ \\
\hline 2. & student $\rightarrow$ course coordinator (S-CC) & $\begin{array}{l}\text { A student initiates a discussion and directs it to the course } \\
\text { coordinator }\end{array}$ \\
\hline 3. & student $\rightarrow$ group (S-G) & $\begin{array}{l}\text { A student initiates a discussion with his/her own group of } \\
\text { classmates }\end{array}$ \\
\hline 4. & tutor $\rightarrow$ group (T-G) & $\begin{array}{l}\text { A tutor initiates a discussion with his/her own group of } \\
\text { students }\end{array}$ \\
\hline 5. & student $\rightarrow$ tutor (S-T) & A student initiates a discussion and directs it to his/her tutor \\
\hline 6. & tutor $\rightarrow$ student (T-S) & $\begin{array}{l}\text { A student initiates a discussion and addresses it to another } \\
\text { student }\end{array}$ \\
\hline
\end{tabular}


We adopted the Hofstede national culture framework to analyze the impact of national cultural diversity on the learners of the two universities. The first dimension, Power Distance refers to the degree a society's culture has respect for authority. A high power distance society is described as having teacher-centered teaching and learning. Individualism refers to culture which emphasizes individual goals and encourages members in the society to be independent while collectivism culture emphasizes on teams, groups, families and society as a whole. Masculine roles refer to assertiveness, competition, and toughness and feminine roles refer to people-orientation and tenderness. The last dimension uncertainty avoidance refers to the degree in which members of a society cope with uncertainty of the future and tolerance of ambiguity. The learning environment of a society with a high degree of uncertainty avoidance tends to be more structured, maintaining group harmony towards a teaching mode.

Using a content analysis approach, every posting in the asynchronous forum boards and synchronous chat sessions was read, examined and manually analyzed. Two independent researchers participated in the classification of the exchanges within the dimension of interaction to ensure reliability and consistency in the process based on the framework defined.

We defined a single interaction by examining the instructional intention and the type of discussion. After investigating the pattern of tutor-learners-course coordinator interactions and the depth of the discussions, the interactions were coded and classified into the five dimensions, along with initiator and respondent communications in the various categories of exchanges. If a single exchange involved multiple interactions, we will record as per the most dominant interaction.

To examine the depth of the discussions, we analyzed the thread levels of discussions. Thread 1 indicates that the initiator's posting did not have any ensuing reply while Thread 2 denotes a single reply to the initiator's posting that shows a two-way communication ensued and so on. A higher thread number denotes a discussion that has progressed to deeper and more complex levels.

\section{RESULT AND DISCUSSION}

From Table 3, it is noted that the average age, language used and the mother tongue of the learners' profile are different in the both the SHTVU and WOU. The common language background of learners and the language used in LMS are the same in SHTVU and the average age of learners in WOU is 3.6 year older than the learners in SHTVU. In WOU, the learners came from various racial backgrounds where different languages are used but English is used in the LMS. More than half of the discussion in SHTVU was actually initiated by female learners, as compared to WOU which was the opposite. Table 5 depicts SHTVU LMS number and types of interaction while Table 6 portrays WOU LMS number and types of interaction. Table 7 describes the thread level of discussions in SHTVU LMS and Table 8 shows the thread level of discussions in WOU LMS. Table 9 represents the number of participants in the LMS and Table 10 shows the number of postings by chat sessions and forum boards. 
Table 5. SHTVU LMS: Number and Types of Interactions

\begin{tabular}{|l|c|c|c|c|c|c|c|l|}
\hline \multicolumn{1}{|c|}{ Dimension } & CC-G & S-CC & S-G & T-G & S-T & T-S & \multicolumn{2}{|c|}{ Total } \\
\hline Cognitive & 1 & 3 & 12 & 2 & 14 & 0 & 32 & $6.9 \%$ \\
\hline Explanatory & 0 & 1 & 6 & 3 & 44 & 0 & 54 & $11.7 \%$ \\
\hline Expository & 0 & 2 & 12 & 1 & 28 & 0 & 43 & $9.3 \%$ \\
\hline Procedural & 3 & 61 & 49 & 9 & 86 & 1 & 209 & $45.1 \%$ \\
\hline Social & 1 & 29 & 51 & 7 & 37 & 0 & 125 & $27.0 \%$ \\
\hline \multirow{2}{*}{ Total } & 5 & 96 & 130 & 22 & 209 & 1 & 463 & $100 \%$ \\
\cline { 2 - 8 } & $1.1 \%$ & $20.7 \%$ & $28.1 \%$ & $4.8 \%$ & $45.1 \%$ & $0.2 \%$ & $100 \%$ & \\
\hline
\end{tabular}

Table 6. WOU LMS: Number and Types of Interactions

\begin{tabular}{|l|c|c|c|c|c|c|c|l|}
\hline \multicolumn{1}{|c|}{ Dimension } & CC-G & S-CC & S-G & T-G & S-T & T-S & \multicolumn{2}{|c|}{ Total } \\
\hline Cognitive & 6 & 3 & 10 & 17 & 3 & 0 & 39 & $9.3 \%$ \\
\hline Explanatory & 3 & 2 & 38 & 59 & 18 & 0 & 120 & $28.5 \%$ \\
\hline Expository & 4 & 1 & 12 & 80 & 15 & 0 & 112 & $26.6 \%$ \\
\hline Procedural & 18 & 8 & 9 & 43 & 3 & 0 & 81 & $19.2 \%$ \\
\hline Social & 6 & 1 & 24 & 31 & 7 & 0 & 69 & $16.4 \%$ \\
\hline Total & 37 & 15 & 93 & 230 & 46 & 0 & 421 & $100 \%$ \\
\cline { 2 - 8 } & $8.8 \%$ & $3.6 \%$ & $22.1 \%$ & $54.6 \%$ & $10.9 \%$ & $0 \%$ & $100 \%$ & \\
\hline
\end{tabular}

Table 7. SHTVU LMS: Thread Levels of Discussions

\begin{tabular}{|l|c|c|c|c|c|}
\hline \multirow{2}{*}{ LMS } & \multicolumn{4}{|c|}{ Frequency } & \multirow{2}{*}{ Total } \\
\cline { 2 - 5 } & Thread $=1$ & Thread $=2$ & Thread $=3$ & Thread $\geq 4$ & \\
\hline Headquarters & 37 & 97 & 16 & 30 & 180 \\
\hline Learning Centers & 114 & 134 & 19 & 16 & 283 \\
\hline Total & 151 & 231 & 35 & 46 & 463 \\
\cline { 2 - 5 } & $32.6 \%$ & $49.9 \%$ & $7.5 \%$ & $10 \%$ & \\
\hline
\end{tabular}

Table 8. WOU LMS: Thread Levels of Discussions

\begin{tabular}{|l|c|c|c|c|c|}
\hline \multirow{2}{*}{ Forum Heading } & \multicolumn{4}{c|}{ Frequency } & \multirow{2}{*}{ Total } \\
\cline { 2 - 6 } & Thread $=1$ & Thread $=2$ & Thread $=3$ & Thread $\geq 4$ & \\
\hline Announcements from CC to Students & 4 & 1 & 2 & 27 & 34 \\
\hline Public Forum & 3 & 11 & 8 & 36 & 58 \\
\hline Forming Study Groups & 7 & 5 & 2 & 9 & 23 \\
\hline Chat Sessions & 0 & 0 & 0 & 15 & 15 \\
\hline Announcements from Tutor & 102 & 38 & 26 & 50 & 216 \\
\hline Group Forum & 10 & 19 & 17 & 29 & 75 \\
\hline Total & 126 & 74 & 55 & 166 & 421 \\
\cline { 2 - 6 } & $29.9 \%$ & $17.6 \%$ & $13.1 \%$ & $39.4 \%$ & \\
\hline
\end{tabular}


Table 9. Number of Students Participated in the Chat Sessions and Forum Boards of SHTVU and WOU

\begin{tabular}{|c|c|c|c|c|c|c|c|c|c|c|c|c|c|c|c|c|}
\hline \multirow{3}{*}{$\begin{array}{c}\text { Number of } \\
\text { Participants } \\
\text { in the LMS } \\
\text { of: }\end{array}$} & \multicolumn{4}{|c|}{$\begin{array}{c}\text { Synchronous Chat } \\
\text { Sessions }\end{array}$} & \multicolumn{4}{|c|}{$\begin{array}{c}\text { Asynchronous Forum } \\
\text { Boards }\end{array}$} & \multicolumn{4}{|c|}{$\begin{array}{l}\text { No. of Students } \\
\text { Participated }\end{array}$} & \multicolumn{4}{|c|}{ Total Students Enrolled } \\
\hline & \multicolumn{2}{|c|}{ SHTVU } & \multicolumn{2}{|c|}{ WOU } & \multicolumn{2}{|c|}{ SHTVU } & \multicolumn{2}{|c|}{ WOU } & \multicolumn{2}{|c|}{ SHTVU } & \multicolumn{2}{|c|}{ WOU } & \multicolumn{2}{|c|}{ SHTVU } & \multicolumn{2}{|c|}{ WOU } \\
\hline & $\mathrm{n}$ & $\%$ & $n$ & $\%$ & $\mathrm{n}$ & $\%$ & $\mathrm{n}$ & $\%$ & $n$ & $\%$ & $n$ & $\%$ & $\mathrm{n}$ & $\%$ & $\mathrm{n}$ & $\%$ \\
\hline $\begin{array}{l}\text { Head- } \\
\text { quarters }\end{array}$ & 43 & 3.0 & 23 & 6.4 & 86 & 5.9 & 80 & 22.2 & 121 & 8.3 & 93 & 25.8 & 1451 & 100 & 361 & 100 \\
\hline $\begin{array}{l}\text { Learning } \\
\text { Centers }\end{array}$ & 84 & 35.9 & 0 & 0 & 8 & 3.4 & 71 & 19.7 & 86 & 36.8 & 71 & 19.7 & 234 & 100 & 361 & 100 \\
\hline
\end{tabular}

Table 10. Number of Interactions in the Chat Sessions and Forum Boards of SHTVU and WOU

\begin{tabular}{|c|c|c|c|c|c|c|c|c|c|c|c|c|}
\hline \multirow[t]{3}{*}{$\begin{array}{l}\text { Number of Interactions in } \\
\text { the LMS of: }\end{array}$} & \multicolumn{4}{|c|}{$\begin{array}{l}\text { Synchronous Chat } \\
\text { Sessions }\end{array}$} & \multicolumn{4}{|c|}{$\begin{array}{c}\text { Asynchronous Forum } \\
\text { Boards }\end{array}$} & \multicolumn{4}{|c|}{ Total No. of Interactions } \\
\hline & \multicolumn{2}{|c|}{ SHTVU } & \multicolumn{2}{|c|}{ WOU } & \multicolumn{2}{|c|}{ SHTVU } & \multicolumn{2}{|c|}{ WOU } & \multicolumn{2}{|c|}{ SHTVU } & \multicolumn{2}{|c|}{ WOU } \\
\hline & $\mathrm{n}$ & $\%$ & $\mathrm{n}$ & $\%$ & $n$ & $\%$ & $\mathrm{n}$ & $\%$ & $\mathrm{n}$ & $\%$ & $\mathrm{n}$ & $\%$ \\
\hline Headquarters & 65 & 36.1 & 15 & 11.5 & 115 & 63.9 & 115 & 88.5 & 180 & 100 & 130 & 100 \\
\hline Learning Centers & 274 & 96.8 & 0 & 0 & 9 & 3.2 & 291 & 100 & 283 & 100 & 291 & 100 \\
\hline Total & \multicolumn{2}{|c|}{339} & \multicolumn{2}{|c|}{15} & \multicolumn{2}{|c|}{124} & \multicolumn{2}{|c|}{406} & \multicolumn{2}{|c|}{463} & \multicolumn{2}{|c|}{421} \\
\hline
\end{tabular}

Analyzing results depicted in Table 5, we found that the Procedural dimension of interaction was the most dominant (45.1\%) in SHTVU, followed by Social (27.0\%), Explanatory $(11.7 \%)$, Expository $(9.3 \%)$ and the least dominant dimension was Cognitive $(6.9 \%)$. Most messages were S-T, followed by the exchanges with classmates. The least dominant category of exchanges was T-S. Based on Table 7, we observed that most forum exchanges (49.9\%) proceeded to the second thread while $32.6 \%$ exchanges remained in the first thread. About 10 $\%$ of the discussions proceeded to the fourth thread and beyond.

The Explanatory dimension of interaction appears to be the most dominant (28.5\%) in WOU, followed by Expository (26.6\%), Procedural (19.2\%) and Social (16.4\%). The least dominant dimension was Cognitive (9.3\%), as depicted in Table 6. Most messages were in the T-G category of exchanges (54.6\%) while S-G category accounted for $22.1 \%$. The least dominant was the category of exchanges of S-CC which was about 3.6\%. There were no messages initiated in the T-S categories as the students used the message function to communicate with individual students or tutors. Analyzing Table 8, we noted that most forum exchanges in WOU were in the fourth thread of interactions and beyond (39.2\%), with about $29.5 \%$ of the discussions remaining at the first level. About $17.9 \%$ of discussions proceeded to the second thread and $13.3 \%$ went on to the third thread level.

Based on Table 9 and Table 10, with regards to the learners' participation in the forum boards and chat session, we found that in the LMS platform of SHTVU headquarter, more learners participated in the asynchronous forum boards (5.9\%) compared to the synchronous chat sessions (3\%). We found the opposite for the learners' participation in the platform of learning centers. In WOU, the chat sessions were conducted by the CC at the headquarters level. Besides, learners' participation rate was observed to be higher in WOU forums at head 
quarters level as compared to SHTVU. Examining the number of interactions of SHTVU, the interactions were more at the headquarter forum boards (61.5\%) as compared to the number of interactions in synchronous chat sessions (38.5\%). However, at the learning centers LMS platform, number of interactions in the synchronous chat sessions (96.8\%) was more than the asynchronous forum boards (3.4\%). As for WOU, it can be noted that majority of discussions and interactions happened in the asynchronous forum boards conducted at learning centers level.

In terms of exchanges, SHTVU obtained the highest level of interaction in the S-T category, registered at $44.5 \%$. When Chinese learners encounter challenges in their studies, most of them prefer to use LMS and have direct contact with their tutor in order to gain more information. The environment of a web-based learning process offers a learning experience with a difference. Online learners are able to bridge the distance or close the gap between learners and tutors easily. A web-based learning environment also reduces the negative effects of the power distance factor. Meanwhile, the high T-G interaction level (about 54.6\%) in WOU indicates that the ODL in Asia is still very tutor-centered. The tutor plans learning tasks and follow up with directives or instructions. As such, in Malaysia, the influence of the power distance factor is high compared to China and world average.

In the dimension of interactions, SHTVU shows the highest activity level in the Procedural category (reaching nearly $44.7 \%$ ). The demand for skilled manpower and higher education increases in tandem with China's rapid social development and economic growth. More Chinese are considering continued education program and retraining in order to gain personal prestige and improve their socio-economic standing. With many formal education setups still heavily exam-orientated, learners' questions and concerns still tend to gravitate towards examination procedures and strategies. This also implies that the influence of Collectivism is higher in China than in Malaysia. In the depth of discussion, statistics for SHTVU indicate a high level of Thread 2 interaction activity. This is due to the fact that most exchanges were at the Procedural dimension level and were geared towards obtaining a single direct answer to a query.

For dimension of interactions, the Explanatory dimension of WOU reached $28.5 \%$. Furthermore, about $39.4 \%$ of the WOU learners achieved depth of discussion of thread 4 or higher. The findings indicate that learners in Malaysia aim to gain more knowledge in their learning activities. At the same time, the results also imply that the learners in Malaysia are quite independent and could easily adapt to a web-based mode of education. This implies that individualism is higher in Malaysian culture with lower degree of uncertainty avoidance.

In our opinion, the low S-S exchanges and relatively few cognitive interactions in the SHTVU forum discussions were mainly to the Chinese Confucian values which believe that the teacher nor students should be put in a position to suffer "loss of face" or embarrassment. Students are found to be unwilling or reluctant to comment on others' opinion or ideas posted in the forums and this reflects the higher degree of collectivism as well. Meanwhile for the dimension of interactions, the social aspect reached $27.4 \%$. The LMS, besides acting as a platform for learning materials, also enables learners to establish friendships with their counterparts. Web- 
based interactions not only fulfilled the learning requirement, but also fulfilled the social need for bonding and friendship. This finding also highlights the elements of collectivism in China's culture. Our finding also noted that in SHTVU, the majority of discussions were initiated by female learners. In the Chinese society today, both females and males are playing their social role in a significantly more equitable way. The gender gap in China is gradually becoming smaller. The education opportunities for males and females are generally equal.

In addition, in SHTVU, more students participated actively in the LMS discussions at the learning centers level, as compared to LMS conducted at the headquarter level, in which most discussions were actually happened in the synchronous chat sessions. As tutor is online and able to give real time response, learners of SHTVU are more willing to take part in synchronous chat sessions. This can be seen as teacher-centered teaching and learning as rooted in the cultural background of Asian learners. On the other hand, this also reflected that the power distance indicator of the two countries is much higher than the world average. WOU learners participated more in the LMS organized and opened to all students (at headquarter level) and this indicates that the Malaysian learners are higher in individualism.

Based on the above findings, we noticed that culture diversity will have a momentous impact on learners' web-based interaction behavior. Although both universities are located in Asia, the culture of their respective regions, to certain extent, are quite different. Therefore, the learners learning and interaction behavior is also expressed and conducted differently. Clearly, cultural diversity influences web-based learning and interaction behavior in the following aspects:

The initiator of web-based interaction: In the feminine-orientated type of culture and society, learners' activities have progressed beyond gender constraints - both the male and female learners have actively participated in web-based interaction. On the other hand, in the power distance-orientated society, the tutor frequently functions as the initiator of web-based interaction, with learners seldom taking the initiative to commence the interaction process.

The thread levels in discussions: Thread levels depend on whether learners are willing to openly comment on others' viewpoints. Chinese learners, most of them are influenced by the traditional Confucian culture, are reluctant to aggressively display knowledge in order to avoid being labeled as 'unfriendly'. As such, in order to maintain a good relationship, most learners do not openly criticize or comment on other learners' viewpoints. Most of the Chinese learners prefer the assistance of the tutor to directly solve their learning problems. Therefore, the ensuing discussions remained mostly in the level 2 category.

The depth of interaction: The creation and exchange of knowledge is built on the basis of self and independent thinking, not on simply following others' opinion or thoughts (meaning to always say 'yes' to others). Learners who are highly individualistic would be confident enough to voice out their independent thoughts and viewpoints. The level of their web-based interaction is significantly deeper.

The content and benefit of web-based interaction: Web-based interaction is the key tool to connect among learners. Apart from learning interaction for reference materials, web-based 
LMS also becomes the bridge to establishing friendships - for working closely with each other to solve the learning challenges faced. Thus, web-based interaction not only fulfills the learning of academic requirements, but provides an avenue for social networking as well. This trend may be clearly observed in those learners with a high sense of collectivism.

\section{CONCLUSION}

Based on the above analysis, we conclude that learners from different national cultural backgrounds have demonstrated varied web-based interaction behavior. The web-based interaction activities of the learners are influenced by their respective regional or national culture. Culture is the collective/shared value or perspective adopted or practiced by the people in a certain country or region. The members of society utilize cultural values and conventions to cope with their world and with one another, and the elements of culture are transmitted to later generations through socialization and learning.

It is a fact that culture and cultural institutions have an enduring resilience. As such, the values and practices of a certain culture will not be easily affected or transformed despite being subjected to the forces of external change. The effects of traditional culture towards learning activities are still deeply entrenched in spite of the growing prevalence of new ways and modes of learning. While more analysis needs to be undertaken, this study has discovered various possible ways to improve and encourage learner interaction in online discussions.

In societies with a higher degree of power distance effect, quite a number of learners are known to have acted as readers who did not ask any questions. These groups of learners often wait for the tutor to define their responsibility, and may directly relay their doubts to the tutor. It is crucial to help the learner, regardless of the influence of background culture, to gain a level of confidence in learning, which will lead to greater satisfaction in acquiring and synthesizing knowledge. This factor is crucial as it boosts the learner's satisfaction and interest, and encourages participation in web-based discussions in a more meaningful way.

In societies with a higher degree of masculine-orientation, tutors need to look more into female learners' learning activities. In Chinese society, female learners are usually seldom involved in the decision-making activities and seldom disclose their own view points. Most of them are implementers rather than decision-makers. However, the activities in the learning process require every learner to demonstrate independent thinking, to bravely voice out their views and to be involved in commenting on others' viewpoints. These intellectual processes and discussions would greatly enhance the acquisition of knowledge and understanding. Tutors should support and encourage female learners to participate more in web-based interaction, and positively affirm them when they show improvement and progress.

Web-based interaction is the key tool to network with other learners. Besides interacting on issues related to learning materials via LMS, learners also communicate and strengthen friendship networks through web-based interaction. Learners who are collective-orientated could also satisfy their social needs besides fulfilling the learning requirement. Social dimension of web-based interaction would foster cooperation among the learners. When faced with challenges in the learning process, learners would utilize the internet to assist each other. 
Timely and appropriate training is crucial to equip tutors with necessary facilitation skills towards enhancing learner-centered interaction in the web-based learning environment, acknowledging the fact that tutors are managers of learners learning experience.

From the perspective of information transmission, the interaction of online learning via the web lacks the range of physical expressions and the stimulus of sound. Learners do not experience the impact of live hearing and seeing, but only communication via words. This type of communication is perceived to be less intimate and animated, increasing the feeling of loneliness and alienation experienced by the learners. The learner's experience in the first few weeks of the semester is believed to deeply affect the subsequent learning behavior of the learners. This is the transition period for learners to shift from a traditional learning approach to a new web-based learning environment. Teachers and tutors need to capitalize on various techniques to break the ice as well as to create a friendly web-based learning environment, in order to eliminate the gap caused by distance and non-face to face communication. Once the learners are used to the web-based communication environment, they will adopt and participate in online communication as one of the crucial learning tools available to them.

As ODL learners tend to feel lonely throughout their journey of acquiring knowledge, timely feedback plays a vital role to eliminate the negative feelings associated with on-line learning. Feedback can be broadly defined as the exchange of information between learner-instructor, learner-learner and learner-LMS with regard to an action, event, or process that results in enhanced student learning. A number of researchers have studied the importance of feedback (Chickering \& Gamson, 1987; Chickering \& Ehrmann, 1996; Sciuto, 2002; Soon et al., 2000). All of them agreed that feedback is critical to assessment and provides students information about their progress in the course. Both asynchronous forum exchanges and synchronous chats are good ways to provide timely feedback. Nonetheless, either due to the large number of students or perhaps the small number of teachers, the difficulties of insufficient feedback persists, in spite of the initiative taken by teachers, tutors and learners to solve the problem.

The learning activities of learners are influenced by various factors, including learning style, capability of using information technology, the attitude of learners towards the internet and computer, as well as the influence of regional and national culture. Amongst all these, the influence of regional and national culture should not be neglected or underestimated. Unlike other influences, the impact of culture is always ingrained and indirect, and will take a longer time to modify or change. For instance, a learner may only require a few weeks to master a range of computer skills, but the impact of culture will require a longer time to be changed, on assumption that it can even be altered at all.

The development of information technology has enabled enthusiastic learners to gain equivalent learning opportunities. Nonetheless, information technology is largely unable to provide a solution for all the problems encountered along the learning journey. Hence, the bearing that culture will not be eliminated with the advancement of technologies and learning techniques. In line with the progress and openness of societies today, as well as the on-going adaptation of new learning approaches, the learning behavior of learners via the Internet is 
expected to continuously change, reflecting the progress of lifestyle-changing information technology. Acknowledgement of this fact brings a realization of the many strategies that will need to be implemented to upgrade the efficiency of the online learning process.

This study can be expanded to cover larger sample size and to include analyzing the interaction in courses of a different nature as well as across different cohorts of students in future research undertakings. We acknowledge that there is no single unified culture for a nation, especially with regard to a multi-racial country such as Malaysia. Even in China, there are various ethnicities with different backgrounds which imply different degrees of assimilation of the national culture among the ethnic groups in the same nation. A questionnaire survey can be administered and interviews can be conducted with the learners to better understand how their cultural background affects their interaction. In addition, patterns of interaction in the forum discussion boards can be analyzed throughout the duration of the semester, rather than just a snap-shot at the end of the semester. Besides, interactions in asynchronous forum boards and synchronous chats can be analyzed separately. Learners interaction in a webbased environment is not confined to just online forum boards and chats, but can also be expanded to include studies on how learners interact with the other dimensions of content and self, as mentioned and explained in the related literature.

The authors gratefully acknowledge the assistance provided by Associate Professor Yuan Wei, the Course Coordinator for Principles of Management Studies in SHTVU for her invaluable support in conducting this study.

\section{REFERENCES}

Bauer, C., Chin, K.L. \& Chang, V. (2000). Web-based learning: Aspects of cultural differences. 8th European Conference on Information Systems, Trends in Information and Communication Systems for the 21st Century. ECIS 2000. Austria. Retrieved July 1, 2007, from http://csrc.lse.ac.uk/asp/aspecis/20000068.pdf

Chickering, A. W., \& Gamson, Z. F. (1987). Seven principles for good practice in undergraduate education. AAHE Bulletin, 39(7), 3-6.

Chickering, A. W., \& Ehrmann, S. C. (1996). Implementing the seven principles: Technology as lever. Retrieved January 3, 2004, from the World Wide Web: http://www.tltgroup.org/programs/seven.html

Conner, M. (2000). Global Implications of e-learning. Retrieved July 1, 2007, from http://www.linezine.com/2.1/features/mcgie.htm

Garrison, D. R. \& Cleveland-Innes, M. (2005). Facilitating Cognitive Presence in Online Learning: Interaction is not enough. American Journal of Distance Education, 13(3), 133-148

Garrison, D. R. (1997). Computer conferencing and distance education: Cognitive and social presence issues. The new learning environment: a global perspective. ICDE World Conference, Pennsylvania State University.

GLOBE (2007). Global leadership and organizational behavior effectiveness, research project home page. Retrieved July 1, 2007, from

http://www.thunderbird.edu/wwwfiles/ms/globe/ 
Gunawardena, C. N. \& Zittle, F. (1997). Social presence as a predictor of satisfaction within a computer mediated conferencing environment. American Journal of Distance Education, 11 (3), 8-26.

Harasim, L. (1997). Interacting in hyperspace, in University of Maryland System Institute for Distance Education and International University Consortium Conference on Learning, Teaching Interacting in Hyperspace: The Potential of the Web. Retrieved July 1, 2007, from: http://umuc.edu/ide/potentialweb97/harasim.html

Hofstede, G. (1980). Culture's consequence: International differences in work-related values. Newbury Park: Sage Publications.

Hofstede, G. (1986). Cultural differences in teaching and learning. International Journal of Intercultural Relations, 10, 301-320. Retrieved July 1, 2007, from http://people.bath.ac.uk/edsjcc/hofstededimensions.htm

Hofstede, G. (1991). Cultures and organizations: Software of the mind. London: McGraw-Hill.

Kearsley, G. (1995). The nature and value of interaction in distance learning. Third Distance Education Research Symposium. May 18-21 1995. Retrieved July 1, 2007, from http://www.mat.unb.br/ead/interac.html

Kim, K. J. \& Bonk, C.J. (2002). Cross-cultural Comparisons of Online Collaboration. Journal of Computer-Mediated communication, 8 (1). Retrieved July 1, 2007, from http://jcmc.indiana.edu/vol8/issue1/kimandbonk.html

Moore, M. G. (1989). Three types of interaction. The American Journal of distance Education, 3 (2), 1-6.

Munro-Smith, N. (2002). A tale of two cities: Computer mediated teaching and learning in Melbourne and Singapore. Winds of change in the sea of learning 19th ASCILITE Conference. Auckland, New Zealand. Retrieved July 1, 2007, from http://www.ascilite.org.au/conferences/auckland02/proceedings/papers/105.pdf

Oliver, R \& McLoughlin, C. (1997a). Interactions in audio-graphics and learning environments. The American Journal of Distance Education, 11 (1), 34-54

Oliver, R \& McLoughlin, C (1997b). Interactivity in telelearning environments: Using communications and dialogue meaningfully in the learning process. Retrieved July 1 , 2007, from http://elrond.scam.ecu.edu.au/oliver/docs/97/ODLAA2do.pdf

Oliver, R., Omari, A. \& Herrington, J. (1997). Exploring student interaction in collaborative World Wide Web learning environments. ED-MEDIA/EDTELECOM 1997. Calgary, Canada, II, 812-817. Retrieved July 1, 2007, from http://ecu.edu.au/oliver/docs/97/EM1doc.pdf

Othman, S.A.S. (2005). The Open University Malaysia learning management system: A study interaction in the asychronous forum board. International Journal of Instructional Technology and Distance Learning, 2 (11).

Picciano, A. G. (2002). Beyond student perceptions: Issues of interaction, presences and performance in an online course. Journal of Asynchronous Learning Networks, 6 (1), $21-40$

Robson, J. (1996). The effectiveness of teleconferencing in fostering interactions in distance learning education. Distance Education, 17 (2), 304-334

Rourke, L., Anderson, T., Garrison, D. R. \& Archer, W. (1999). Assessing social presence in asynchronous text-based computer conferencing. Journal of Distance Education, 14 (2) $50-71$ 
Sciuto, G. T. (2002). Setting students up for success: The instructor's role in creating a positive, asynchronous, distance education experience. Virtual University Gazette. Retrieved January 2, 2004, from the World Wide Web: http://www.geteducated.com/vug/aug02/vug0802.htm

Soon, K. H., Sook, K. I., Jung, C. W., \& Im, K. M. (2000). The effects of Internet-based distance learning in nursing. Computers in Nursing, 18, 19-25.

Thurmond, V. \& Wambach, K. (2004). Understanding Interactions in Distance Education: A Review of the Literature, International Journal of Instructional Technology and Distance Learning, from the World Wide Web: http://itdl.org/journal/Jan_04/article02.htm

Tylee, J. (2001). Cultural issues and the online environment. Retrieved July 1, 2007, from http://www.csu.edu.au/division/landt/resources/documents/cultural_issues.pdf 